\title{
Energy intake and expenditure in 1-3-year-old Ugandan children living in a rural environment
}

\author{
By INGRID H. E. RUTISHAUSER AND R. G. WHITEHEAD \\ Medical Research Conncil Child Nutrition Unit, \\ PO Box 6717, Kampala, Uganda \\ (Received 22 November 1971 - Accepted 2 February 1972)
}

\begin{abstract}
I. In a prospective study of Ugandan children during the 2 nd and $3 \mathrm{rd}$ years of life, energy intakes $30 \%$ below the recommended level were frequently found. Despite this the children gained weight at rates similar to those of healthy English children.

2. In view of the low-energy intakes, the activity of the children was studied using a modified form of the diary method of recording activities. European children living under the same climatic conditions were also studied by this method.

3. The Ugandan children spent significantly less time than the European children in activities involving a relatively high rate of energy expenditure such as walking and running.

4. This disparity could account for a difference in energy expenditure of the order of $20 \mathrm{kcal}(84 \mathrm{~kJ}) / \mathrm{kg}$ body-weight per $\mathrm{d}$. The implications are discussed.
\end{abstract}

During the course of a prospective study on a group of Ugandan children living in an environment where kwashiorkor is common, it was observed that in the and and

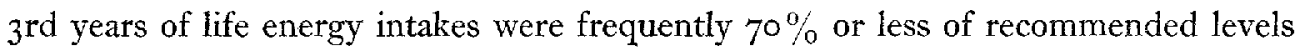
(approximately Ioo kcal $/ \mathrm{kg}$ for children aged $\mathrm{I}-3$ years: Department of Health and Social Security, 1969). In spite of this, many children were able to gain weight and height at rates similar to those of healthy English children (Tanner, Whitehouse \& 'Iakaishi, 1966), who are known to have much higher energy intakes (Widdowson, I947). Low energy intakes in children living in areas generally associated with protein malnutrition have also been reported by Gopalan (1968) and Sukhatme (1970).

It seemed that either considerably less than the internationally recommended energy intake was required by these children or, alternatively, that they were being forced to compensate for the low-energy intake in some way other than by reducing their rate of growth. It is a common impression that Ugandan children living in a traditional rural environment are less active than European children of the same age and living under the same climatic conditions (Welbourn, 1955). An objective assessment of their activity has, however, not previously been made. It was decided therefore to investigate the possibility that these children were able to maintain a virtually normal rate of growth because of a reduction in activity, thus lowering their energy requirements.

\section{EXPERIMENTAL}

\section{Children}

The African children studied, aged between I 8 months and 3 years, were living in a rural environment in the vicinity of a small trading centre about $25 \mathrm{~km}$ from Kampala. All had been seen regularly since the age of 6 months as part of a comprehensive 
longitudinal study into the aetiology of kwashiorkor in Uganda. Sixty children were initially selected and in thirty-two of these serial dietary investigations were carried out; the twenty children reported here were from this group.

The children who made up the control group for the activity study were the sons and daughters of expatriate professional staff and were also aged i 8 months to 3 years. All of them had lived in a tropical environment for at least 6 months at the time of the study.

\section{Anthropometry}

The children were weighed without clothes at every clinic attendance on an Avery person scale (Type $3306 \mathrm{ABV}$ ) and their lengths were measured monthly with the Harpenden infant measuring table (Holtain; Pembrokeshire). All measurements were made by the same observer.

\section{Energy intake}

Energy intake was estimated by two different methods. The first was a modification of the $24 \mathrm{~h}$ dietary recall technique, which involved asking the mothers, at every clinic attendance, about the food the child had consumed on the previous day. The most commonly eaten local foods were prepared and taken to the clinic together with a selection of such household measures and utensils as are in use in rural homes. The amounts demonstrated by the mothers were then weighed. Energy intakes were calculated from these values from figures for energy content of local cooked foods obtained with a ballistic bomb calorimeter (Miller \& Payne, 1959) and for uncooked foods from the tables of Platt (1962).

The second method involved the collection of duplicate diets for periods of $7 \mathrm{~d}$, approximately once every 3 months. In order to do this, the homes were visited four times during each collection period. Separate, easily distinguishable containers were provided for duplicates of the food presented to the child and for any food which the child did not consume. At the end of each week the total food collected and any leftover food were homogenized separately with distilled water and portions subsequently freeze-dried.

Previous analyses had shown that energy content/g of the dried material was remarkably constant, ranging only between 3.6 and $4.6 \mathrm{kcal}$ in $I 3 \mathrm{I}$ samples, with a mean and standard error of $4.0 \mathrm{kcal}(\mathrm{I} 7 \mathrm{~kJ})$ and $0.02 \mathrm{kcal}(0.08 \mathrm{~kJ})$ respectively. It was therefore considered justifiable to use this value for calculation of the energy content of the diet.

\section{Energy expenditure}

Energy expenditure was estimated by a modified form of the diary method for recording activities. It was decided to use an African observer in the African households and a European observer in the European household, since this was less likely to affect the normal pattern of activity. It also allowed the use of observers already known to the families concerned.

For simplicity, activities were recorded in six main categories - lying down, being carried, sitting, standing, walking and running. These categories were, in fact, further subdivided as follows: lying down and being carried - asleep and awake; sitting and standing - still and active; walking and running - slowly and quickly; but in the final 
Table r. Mean values with their standard errors for weight at midpoint of age-range and gain in weight and height of the African children over a period of 6 months with the weight and gain in weight and height of 50 th percentile English children. *

\begin{tabular}{|c|c|c|c|c|}
\hline $\begin{array}{l}\text { Age range } \\
\text { (years) }\end{array}$ & $\begin{array}{l}\text { No. of } \\
\text { children }\end{array}$ & Weight (kg) & $\begin{array}{l}\text { Weight gain } \\
\text { (kg/year) }\end{array}$ & $\begin{array}{c}\text { Height gain } \\
\text { (cm/year) }\end{array}$ \\
\hline$I \cdot 5 I-2 \cdot 00$ & English children & $\begin{array}{l}\text { II.02 } \\
\text { II. } 95\end{array}$ & $\begin{array}{l}I \cdot 83 \pm 0.14 \\
2.20\end{array}$ & $\begin{array}{l}10.3 \pm 0.9 \\
9.8\end{array}$ \\
\hline $2 \cdot 01-2 \cdot 50$ & $\stackrel{4}{\text { English children }}$ & $\begin{array}{l}10 \cdot 60 \pm 0.70 \\
12 \cdot 95\end{array}$ & $\begin{array}{l}2 \cdot 29 \pm 0.22 \\
2 \cdot 00\end{array}$ & $\begin{array}{l}8 \cdot 3 \pm 0.5 \\
8 \cdot 7\end{array}$ \\
\hline $2.5 I-3.00$ & $\stackrel{{ }^{13}}{\text { English children }}$ & $\begin{array}{l}12.69 \pm 0.33 \\
13.95\end{array}$ & $\begin{array}{l}\text { I. } 92 \pm 0.19 \\
\text { I. } 96\end{array}$ & $\begin{array}{l}8 \cdot 9 \pm 0 \cdot 6 \\
8 \cdot I\end{array}$ \\
\hline
\end{tabular}

analysis these subdivisions were not used since the differences between them could not be interpreted in terms of energy expenditure. Recording was done on a standard proforma divided into ro min periods with separate columns for the activity categories. A tick was placed in the appropriate column for every activity occurring during the Io min period, and the time spent on each activity was later estimated by dividing by the number of ticks. The same form was used both for African and European children, but, in the latter group, the minute during which each new activity commenced was also recorded. It was thus possible to compare the time spent on each activity estimated by the tick method with the actual time. Values given in the text, except where otherwise stated, are those obtained by estimate from the simplified method.

To check the uniformity of recording by the observers, they studied simultaneously thirty Io min periods of activity in a child who had been successfully treated for kwashiorkor in the Unit and was accustomed to the presence of both Africans and Europeans. The two sets of results were not significantly different.

The activity of each child was recorded for two periods of $5 \mathrm{~h}$ on different days. The recording periods were from 08.00 to 13.00 hours and from 13.00 to 18.00 hours. These times were selected to enable the African observer to travel to and from the homes during the hours of daylight. Of the $\mathrm{I} 4 \mathrm{~h}$ during a $24 \mathrm{~h}$ period which were not recorded, the African children spent from 10 to $12 \mathrm{~h}$ in bed and the European children from I I to $13 \mathrm{~h}$. Unrecorded non-resting energy expenditure was therefore, on average, only $3 \mathrm{~h}$ for the African children and $2 \mathrm{~h}$ for the European children. In estimating daily energy expenditure it was assumed that for this period of time the pattern of activity was the same as for the recorded period.

\section{RESULTS}

Rates of growth

Table I shows the mean gain in weight and height of the African children for the 6 -month period during which the energy intake and expenditure studies were carried out. The 5oth percentile for healthy English children (Tanner et al. 1966) over the same age-range is given for comparison. Gain in height was very similar to that of the 
Table 2. Mean energy intake of twenty African children, expressed as kcallkg bodyweight $d$ by two different methods of assessment and from the combined values

\begin{tabular}{|c|c|c|c|c|c|c|}
\hline \multirow[b]{2}{*}{ Subject } & \multicolumn{2}{|c|}{$24 \mathrm{~h}$ recall } & \multicolumn{2}{|c|}{ Duplicate food collection } & \multicolumn{2}{|c|}{ Combined values } \\
\hline & $\begin{array}{l}\text { Energy } \\
\text { intake }\end{array}$ & $\begin{array}{c}\text { No. of days } \\
\text { estimated }\end{array}$ & $\begin{array}{l}\text { Energy } \\
\text { intake }\end{array}$ & $\begin{array}{l}\text { No. of days } \\
\text { estimated }\end{array}$ & $\begin{array}{l}\text { Energy } \\
\text { intake }\end{array}$ & $\begin{array}{l}\text { No. of days } \\
\text { estimated }\end{array}$ \\
\hline $954 \mathrm{I}$ & 71 & 8 & 60 & 14 & 64 & 22 \\
\hline 9677 & 50 & 9 & 54 & I4 & 52 & 23 \\
\hline 9689 & $9 \mathrm{I}$ & 9 & 59 & 7 & $8 \mathrm{I}$ & 16 \\
\hline 9155 & 80 & 7 & 66 & 14 & 71 & $2 I$ \\
\hline 9189 & 47 & 9 & 53 & 14 & $5 \mathrm{I}$ & 23 \\
\hline 9207 & 84 & 6 & 64 & 7 & 95 & 13 \\
\hline 9310 & 63 & 12 & 45 & 14 & 53 & 26 \\
\hline 8986 & 48 & 9 & $4 \mathrm{I}$ & I I & 44 & 20 \\
\hline 8989 & 93 & 7 & 73 & 7 & $8_{3}$ & 14 \\
\hline 8990 & 53 & 9 & 61 & 14 & 58 & 23 \\
\hline 8997 & 83 & IO & 72 & 14 & 77 & 24 \\
\hline 8998 & 69 & 8 & 77 & 14 & 74 & 22 \\
\hline 8999 & 68 & 7 & 74 & 14 & 72 & $2 I$ \\
\hline 9024 & 85 & 4 & 63 & 14 & 68 & I8 \\
\hline 9050 & 55 & 6 & 48 & 14 & 50 & 20 \\
\hline 9057 & 66 & 16 & 63 & 14 & 65 & 30 \\
\hline 9105 & 76 & IO & 66 & 14 & 70 & 24 \\
\hline 9227 & 59 & 7 & 66 & 14 & 64 & $2 I$ \\
\hline 9254 & 96 & 6 & 67 & 12 & $7 \mathrm{I}$ & I 8 \\
\hline 9255 & 70 & 5 & 80 & $\mathrm{I}_{4}$ & 77 & 19 \\
\hline an with its SE & $\begin{array}{c}70 \pm 3 \\
(293 \pm 14 \mathrm{~kJ})\end{array}$ & & $\begin{array}{c}65 \pm 3 \\
(272 \pm 13 \mathrm{~kJ})\end{array}$ & & $\begin{array}{c}67 \pm 3 \\
(280 \pm 12 \mathrm{~kJ})\end{array}$ & \\
\hline
\end{tabular}

English children, as was gain in weight with the exception of the youngest children, whose increase in weight was about $20 \%$ lower.

\section{Energy intake}

The mean daily energy intakes of the African children over the same 6-month period, obtained by the two methods of assessment, are shown in Table 2 . 'The energy intakes by both methods were between $4^{1}$ and $96 \mathrm{kcal} / \mathrm{kg}$ body-weight $\mathrm{d}$. All the intakes above $80 \mathrm{kcal} / \mathrm{kg}$ body-weight $\mathrm{d}$, however, were found in children receiving a milk supplement which provided $20-30 \mathrm{kcal} / \mathrm{kg}$ body-weight $\mathrm{d}$. The intakes of most of the children fell between 50 and $70 \mathrm{kcal} / \mathrm{kg}$ body-weight $\mathrm{d}$. The mean energy intake estimated by the recall method ( $70 \mathrm{kcal} / \mathrm{kg}$ body-weight $\mathrm{d}$ ) was slightly higher than that estimated by the food-collection method $(65 \mathrm{kcal} / \mathrm{kg}$ body-weight $\mathrm{d}$ ), but this difference was not statistically significant. The results were therefore combined, thus giving an estimate of energy intake for $\mathrm{I} d$ in every 9 during the period of study. This varied between 44 and $95 \mathrm{kcal} / \mathrm{kg}$ body-weight $\mathrm{d}$, with a mean of $67 \mathrm{kcal}(280 \mathrm{~kJ}) /$ $\mathrm{kg}$ body-weight $\mathrm{d}$. For various reasons, energy intake was only studied in two of the five expatriate children, the youngest and oldest of the group (S.S. and S.H.). The measurements were made for $3 \mathrm{~d}$ by the duplicate food-collection method. The intakes were 108 and $12 \mathrm{Ical} / \mathrm{kg}$ body-weight respectively, estimated by bomb calorimetry. 
Table 3. Measured $(A)$ and estimated $(E)$ time (min) spent in various activities by five European children during a $10 h$ period of observation

\begin{tabular}{|c|c|c|c|c|c|c|c|c|c|c|c|c|}
\hline \multirow[b]{2}{*}{ Subject } & \multicolumn{2}{|c|}{ Lying down } & \multicolumn{2}{|c|}{ Being carried } & \multicolumn{2}{|c|}{ Sitting } & \multicolumn{2}{|c|}{ Standing } & \multicolumn{2}{|c|}{ Walking } & \multicolumn{2}{|c|}{ Running } \\
\hline & A & $\mathbf{E}$ & A & $\mathrm{E}$ & A & $\mathrm{E}$ & $\mathrm{A}$ & $\mathbf{E}$ & $\mathrm{A}$ & $\mathrm{E}$ & $\mathrm{A}$ & $\mathrm{E}$ \\
\hline $\mathrm{AF}$ & 13 & 19 & I & 2 & 232 & 173 & $12 \mathrm{I}$ & 120 & 222 & 263 & I I & 23 \\
\hline SS & 94 & 96 & 106 & 90 & 127 & 117 & $7 I$ & 9 I & I 86 & 179 & 16 & 30 \\
\hline $\mathrm{FB}$ & 39 & 36 & 8 & 16 & I 35 & 126 & 217 & 189 & $18 \mathrm{I}$ & 198 & 20 & 36 \\
\hline $\mathrm{SH}$ & $2 r$ & $2 I$ & 0 & 0 & 210 & 173 & 107 & 122 & 189 & I 92 & 73 & 92 \\
\hline $\mathrm{RA}$ & I I 8 & 120 & 17 & 20 & $25 I$ & 199 & 58 & 72 & I30 & $I_{42}$ & 25 & 46 \\
\hline $\begin{array}{l}\text { Mean with } \\
\text { its SE }\end{array}$ & $\begin{array}{l}57 \pm \\
21\end{array}$ & $\begin{array}{l}5^{8} \pm \\
2 \mathrm{NSS}\end{array}$ & $l_{20}^{26 \pm}$ & $\begin{array}{l}26 \pm \\
x 7 \mathrm{NS}\end{array}$ & $\begin{array}{l}191 \pm \\
25\end{array}$ & $\begin{array}{l}\text { I58土 } \\
\text { 16* }\end{array}$ & $\begin{array}{l}\operatorname{Ir} 5 \pm \\
28\end{array}$ & $\begin{array}{l}119 \pm \\
20 \mathrm{NS}\end{array}$ & $\begin{array}{c}182 \pm \\
\text { I } 5\end{array}$ & ${ }_{20 N S}$ & $\begin{array}{l}29 \pm \\
\text { II }\end{array}$ & $\begin{array}{l}45 \pm \\
12 * *\end{array}$ \\
\hline
\end{tabular}

\section{Energy expenditure}

In Table 3 the actual time spent in various activities by the European children is compared with the estimated time spent in these activities calculated by the simplified method of recording. There was no significant difference between the two methods in assessing the time spent lying down, being carried and standing, which continued for long periods of time. There was, however, a slight tendency for the simplified method to overestimate the time spent walking, and for running this overestimate was significant. The only activity underestimated by the simplified method was sitting. It has been assumed that the errors involved in using the simplified method were of the same order in both groups of children. However, it is likely that, if anything, they were greater in the African children since, in gencral, they were engaged in fewer activities in a ro min period. The effect would be to minimize any differences between the African and European children. The general pattern of activity was very similar for all the European children, the greatest individual variation occurring in the time spent lying down and being carried. The activities which occupied the longest times were walking and sitting.

Table 4 shows the estimated time spent in the various activities by the African children. The pattern of activity again was very similar for all the children but different from that for the Europeans. The greatest individual variation also occurred in the time spent lying down, but the activities occupying the longest periods of time were sitting and standing. There was no significant difference between the two groups in the time spent lying down. There was, however, a significant difference in the time spent on all other activities. The African children occupied more of their time than did the Europeans in sitting and standing but less in being carried, walking or running.

\section{DISCUSSION}

The energy intakes of approximately $70 \mathrm{kcal} / \mathrm{kg}$ body-weight $\mathrm{d}$, found in the African children, were unexpectedly low, especially since the children were still growing. However, similar values have previously been reported for Ugandan children (Welbourn, 1955; McCrae, 1966), and this, together with the fact that two quite different 
Table 4. Estimated time (min) spent in various activities by twenty African children during $a$ io $h$ period of observation

\begin{tabular}{|c|c|c|c|c|c|c|}
\hline Subject & $\begin{array}{l}\text { Lying } \\
\text { down }\end{array}$ & $\begin{array}{l}\text { Being } \\
\text { carried }\end{array}$ & Sitting & Standing & Walking & Running \\
\hline 954I & 45 & Io & 270 & 170 & 105 & 0 \\
\hline 9677 & 153 & 20 & 264 & 112 & 38 & 16 \\
\hline 9689 & 210 & 0 & 185 & 165 & 33 & 6 \\
\hline 9155 & 130 & 0 & 237 & I 55 & 68 & 9 \\
\hline 9189 & 0 & 0 & I9I & 306 & 86 & 18 \\
\hline 9207 & 80 & 20 & 254 & I 66 & 69 & 12 \\
\hline 9310 & 5 & 0 & 150 & 282 & I 6 & 43 \\
\hline 8986 & 27 & 0 & $x^{6} 6$ & 324 & 88 & 23 \\
\hline 8989 & 125 & 0 & 271 & 152 & 45 & 7 \\
\hline $899 \circ$ & 10 & 0 & 274 & 160 & I 45 & 12 \\
\hline 8997 & 0 & 0 & 242 & 272 & 82 & 6 \\
\hline 8998 & o & 0 & 242 & 264 & 77 & I 5 \\
\hline 8990 & 33 & 0 & 186 & 299 & 78 & 5 \\
\hline 9024 & 130 & 50 & 240 & I 16 & 64 & 0 \\
\hline 905० & 0 & 0 & 246 & 205 & 143 & 5 \\
\hline 9057 & o & 0 & 146 & 326 & 119 & 10 \\
\hline 9105 & I I I I & 0 & 243 & 160 & 73 & $I_{3}$ \\
\hline 9227 & 0 & 0 & $26 \mathrm{r}$ & I 54 & 142 & 39 \\
\hline 9254 & 130 & 0 & 246 & 156 & 52 & 14 \\
\hline 9255 & 60 & 0 & 341 & 143 & 52 & 5 \\
\hline
\end{tabular}

Mean with $62 \pm 15$ NS $\quad 5 \pm 3 \dagger \quad 23 \mathrm{r} \pm 1 \mathrm{I} * * \quad 204 \pm 16^{*} \quad 83 \pm 8+\uparrow \dagger \quad$ I $3 \pm 3+1 \dagger$ its SE

Values significantly greater than corresponding estimated value for European children by the $t$ test :

* $P<0.05$; ** $P<0.01$.

Values significantly lower than corresponding estimated value for European children by the $t$ test: $\dagger P<0.05$, t十† $P<0.001$.

NS, not significant.

methods of assessment gave very similar results, makes it unlikely that the energy intakes reported here were underestimated.

It is not difficult to understand why a Ugandan child might have a low-energy intake. In order to achieve the recommended level on a diet in which $85 \%$ of the calories are derived from carbohydrate and which contains little or no milk, he has to consume about twice the weight of food eaten by a European child, whose diet provides only $50 \%$ of the calories from carbohydrate and of which milk forms an essential part. The Ugandan children in the study ate on average $500 \mathrm{~g}$ food/d to achieve an intake of $65 \mathrm{kcal} / \mathrm{kg}$ body-weight d; the two European children who consumed only 210 and $490 \mathrm{~g}$ of food respectively together with $500 \mathrm{ml}$ milk achieved intakes of over I $00 \mathrm{kcal} / \mathrm{kg}$ body-weight $\mathrm{d}$. It would seem therefore that the bulkiness of the diet and its low fat content were primarily responsible for the low-energy intake, rather than poor appetite or climatic conditions. This interpretation has been confirmed in recent studies in our ward (I. H. E. Rutishauser and J. D. L. Frood, in preparation), in which diets of similar composition to those eaten by the children at home were given ad lib. under supervision. Intakes were often only $60-80 \mathrm{kcal} / \mathrm{kg}$ body-weight $\mathrm{d}$ despite the fact that feeding was more frequent than is usual at home.

Conceivably, the children could have a lower energy requirement for restoring metabolism. Indeed, Ablett \& McCance (197I) have shown that the resting metabolic 
Table 5. Estimated energy expenditure of twenty African and five European children calculated from the activity results and expressed as kcallkg body-weight d

\begin{tabular}{|c|c|c|c|c|c|}
\hline \multirow[b]{2}{*}{ Activity } & \multirow[b]{2}{*}{$\mathrm{kcal} / \mathrm{min} \mathrm{kg} *$} & \multicolumn{2}{|c|}{ African } & \multicolumn{2}{|c|}{ European } \\
\hline & & Min & $\mathrm{kcal} / \mathrm{kg}$ & Min & $\mathrm{kcal} / \mathrm{kg}$ \\
\hline Resting in bed & & 660 & $23 \cdot 8$ & 720 & $25 \cdot 9$ \\
\hline Lying down & 0.036 & $8 \mathrm{I}$ & $2 \cdot 9$ & 70 & $2 \cdot 5$ \\
\hline Being carried & & 7 & 0.3 & 31 & $I \cdot I$ \\
\hline Sitting & 0.04 & 300 & I $2 \cdot 0$ & 190 & $7 \cdot 6$ \\
\hline Standing & 0.07 & 265 & I $8 \cdot 6$ & 143 & 10.0 \\
\hline Walking & $0 \cdot 13$ & 108 & $14^{\circ} 0$ & 234 & 30.4 \\
\hline Running & $0.3^{8}$ & 17 & $6 \cdot 5$ & 54 & 20.5 \\
\hline Total/d & & & $\begin{array}{c}7^{8 \cdot 1} \\
(327 \mathrm{~kJ})\end{array}$ & & $\begin{array}{c}98 \cdot 0 \\
(410 \mathrm{~kJ})\end{array}$ \\
\hline
\end{tabular}

* Calculated for a body-weight of $12 \mathrm{~kg}$ from the values given by Durnin \& Passmore (1967), on a direct per $\mathrm{kg}$ basis for sitting and standing and using the equation $C=0.047 W+1.02$ (Passmore \& Durnin, 1955) for walking and running, where $C$ is energy in $\mathrm{kcal} / \mathrm{min}$ and $W$ is body-weight in $\mathrm{kg}$.

rates of children with kwashiorkor are $25 \%$ below normal. However, our children did not have kwashiorkor and Ablett \& McCance ( $197 \mathrm{I}$ ) did demonstrate that apparently healthy Ugandan children from the same environment as those in this study had essentially normal resting metabolic rates. Furthermore, on treatment, the resting metabolic rates of children with kwashiorkor rose rapidly. Thus a low resting metabolic rate is not a likely explanation. Clearly, the children were not compensating for their low-energy intake either by losing weight or by stopping growing, but perhaps this was not very surprising since relatively little energy is required for a normal rate of growth at this age $-4-5 \mathrm{kcal} / \mathrm{kg}$ body-weight $\mathrm{d}$ (Waterlow, i96r; Miller \& Payne, I96I). Thus the only possible explanation for a lower energy requirement would be less energy expenditure associated with activity.

In Table 5 the energy expenditure of the African and European children has been estimated on the basis of the activity results and the energy cost of these activities from the values of Durnin \& Passmore (I967). These values are for somewhat older children, but if they are applicable to younger children the difference in energy expenditure between the Africans and Europeans would be of the order of $20 \mathrm{kcal}$ $(84 \mathrm{~kJ}) / \mathrm{kg}$ body-weight $\mathrm{d}$. This figure is, in fact, about the same as the difference between recommended allowances for energy intake and the energy intakes of the African children; it is obvious that less energy is needed by a child who sits around or stands still than by one who walks or runs a lot.

The real question is whether the relative inactivity of the African children matters. No definite answer can be given to this question at the present time, but the acquisition of motor and mental ability is associated with play activity. It is possible that such important functions might be permanantly impaired if, as a result of relative inactivity, they are not learnt at the correct developmental stage. This possibility is worthy of further study.

There is a further consideration of theoretical importance arising from the results. Miller \& Payne (I96r) showed that growth is limited when energy intake is below 
I $40 \mathrm{kcal} / \mathrm{kg}^{0.73}$, when energy requirements are satisfied preferentially to protein requirements. In the children studicd, whose average weight was $12 \mathrm{~kg}$, this is equivalent to an energy intake of $72 \mathrm{kcal} / \mathrm{kg}$ and very close to the actual level of intake found. It is thus possible to explain both how, with such a low-energy intake, our children could maintain their body-weight and continue to grow and yet why even a short period of anorexia associated with illness, which is a frequent occurrence (Frood, Whitehead \& Coward, I97I), can precipitate them very rapidly into a state of protein deficiency.

Despite the fact that this study can only be regarded as a preliminary one, the results have been reported in some detail since very little published information is available on such basic environmental factors in the development of malnutrition; it is hoped that these findings will stimulate further work in this field.

We would like to acknowledge the valuable discussions we had with Professor C. T. M. Davies and Professor J. S. Weiner, and to thank Mr F. M. Kayirigo, Mrs C. S. Nalikka, Mr K. B. Kaidzi and Sisters J. Kingdon and M. Hood for carrying out the field-work.

\section{REFERENCES}

Ablett, J. G. \& McCance, R. A. (I971). Lancet ii, 5 I7.

Department of Health and Social Security (1969). Rep. Publ. Hlth med. Subj. no. tzo. London: H.M. Stationery Office.

Durnin, J. V. G. A. \& Passmore, R. (r967). Energy, Work and Leisure p. Ioo. London: Heinemann.

Frood, J. D. L., Whitehead, R. G. \& Coward, W. A. (197I). Lancet ii, 1047.

Gopalan, C. (I968). In Calorie Deficiencies and Protein Deficiencies p. 49 [R. A. McCance and E. M. Widdowson, cditors]. London: Churchill.

McCrae, J. E. ( 1966 ). The ecology of malnutrition in a Buganda village, Uganda. MSc Thesis, University of London.

Miller, D. S. \& Payne, P. R. (1959). Br. F. Nutr. I3, 50r.

Miller, D. S. \& Payne, P. R. (1961). F. Nutr. 75, 225.

Passmore, R. \& Durnin, J. V. G. A. (1955). Physiol. Rev. 35, 80 I.

Platt, B. S. (1962). Spec. Rep. Ser. med. Res. Coun. no. 302.

Sukhatme, P. V. (I 970). Br. F. Nutr. 24, 477.

Tanner, J. M., Whitehouse, R. H. \& Takaishi, M. (1966). Archs Dis. Childh. 41, 6г 3.

Waterlow, J. C. (г961). F. trop. Ped. 7, г6.

Welbourn, H. F. (1 955). F. trop. Ped. r, 98.

Widdowson, E. M. (I947). Spec. Rep. Ser. med. Res. Coun. no. 257. 